\title{
DESIGNING AND FABRICATING A SMALL EDM MACHINE
}

\author{
Phan Dinh Huan \\ University of Technology, Hochiminh City \\ National Key Lab of Digital Control and System Engineering, VNU-HCM \\ (Manuscript Received on April $5^{\text {th }}, 2012$, Manuscript Revised November 20 ${ }^{\text {rd }}, 2012$ )
}

\begin{abstract}
The main content of this paper concentrates on studying of designing and manufacturing a small- size electrical discharge machining (EDM) machine in order to meet the domestic demands in the field of machining the geometrically complex shape machine elements, hard materials or in case of severe requirements of precision, surface roughness. These above cases can not be performed with the traditional machining processes. Based on the results of studying the working principle of the EDM method, the solutions for automatically controlling the tool electrode, all necessary materials available in vietnamese market, an EDM machine is successfully constructed. This machine includes the mechanical part, the electrical components (pulse generator), automatic control mechanism of tool electrode, pump system, filter, lighting, etc The initial machining operations have been also realized to determine some important technological parameters as well as to evaluate the obtained machining quality of this machine.
\end{abstract}

Keywords: electrical discharge machining machine, EDM, automatic control mechanism

\section{INTRODUCTION}

The main components of an EDM machine is described in figure 1 . Both the tool usually made of graphite, copper, $\mathrm{Cu}$ - Wo alloy and the workpiece electrodes are connected to a DC pulse generator.The vertical feeding motion of the tool is realized with an automatic control mechanism either with the aid of DC motor, DC servo motor or hydralic cylinder etc. When the gap between the two electrodes is small enough, the materials from both the two electrodes will be removed with the creation of sparks and the flow of the dielectric liquid.

A pump system with filter is necessary to circulate the dielectric mixed with the burning particles. In industry, kerosene is commonly used as the dielectric. This one also plays the role of a coolant for the machined area and is an important factor to determine the sparked gap, the machining precision and the wearness ratio of electrodes etc.

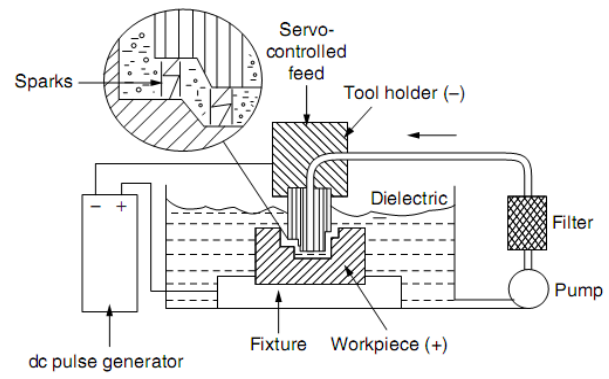

Figure 1. Scheme of EDM method 
Electrodes and some other accessories of an EDM machine are represented in figure 2.

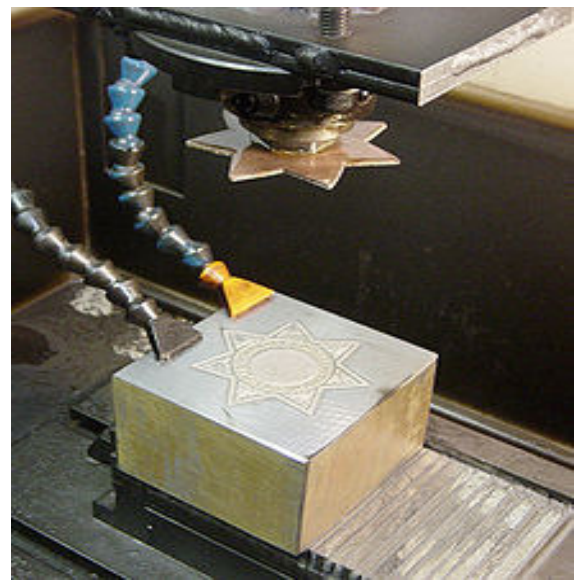

Figure 2. Master at top, badge die workpiece at bottom, oil jets at left (oil has been drained). Initial

flat stamping will be "dapped" to give a curved surface. [8]

Nowadays, sinking EDM machines are commonly used all over the world for many industrial applications. Many succesful researches in the field of designing and fabricating EDM machines are continuously obtained.

Some patents form[5] to [12] relating to EDM machines are introduced in references.

Combining with the technique of $\mathrm{CNC}$, rather complex shape can be created on a sinker EDM machine as shown in figure 3

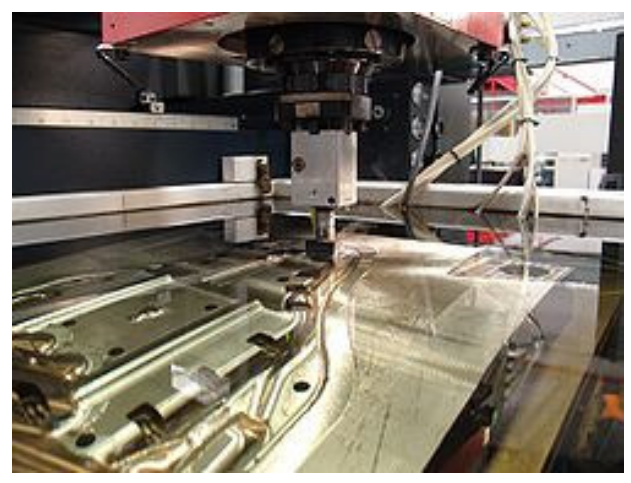

Figure 3. A 3-D complex shaped workpiece machined with a sinker EDM [8]

In Vietnam, many scientific and technical researches have been performed not only in the sector of industry but also in the sector of universities and institutes. Some typical topics can be found in references from [1] to [7].

\section{DESIGNS AND OBTAINED RESULTS}

\subsection{Mechanical Design}

The main features of the fabricated EDM machine can be summarized as follows:

- Overall machine dimensions: $800 \mathrm{~mm} \mathrm{x}$ $800 \mathrm{~mm} \times 1500 \mathrm{~mm}$

- Weight: $400 \mathrm{~kg}$, approximatively.

- $\mathrm{X} \times \mathrm{Y} \times \mathrm{Z}=300 \mathrm{~mm} \times 250 \mathrm{~mm} \times 120$ $\mathrm{mm}$

The two translational motions $\mathrm{X}$ and $\mathrm{Y}$ are manually obtained with the help of a ball screw-nut mechanism. These are motions of the working table that holds the workpieces and fixtures during the machining process. 


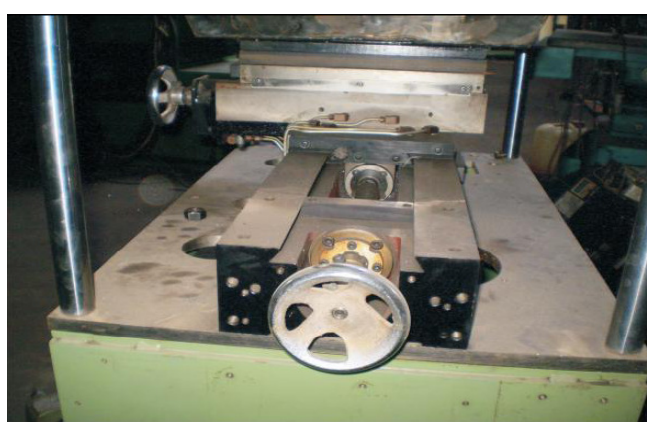

Figure 4 The working table $\mathrm{X}$ - Y

The feeding motion or the $\mathrm{Z}$ motion of the tool electrode is automatically driven with the presence of a DC print motor and the ball screw-nut mechanism combining with the two linear guides as indicated in figure 5

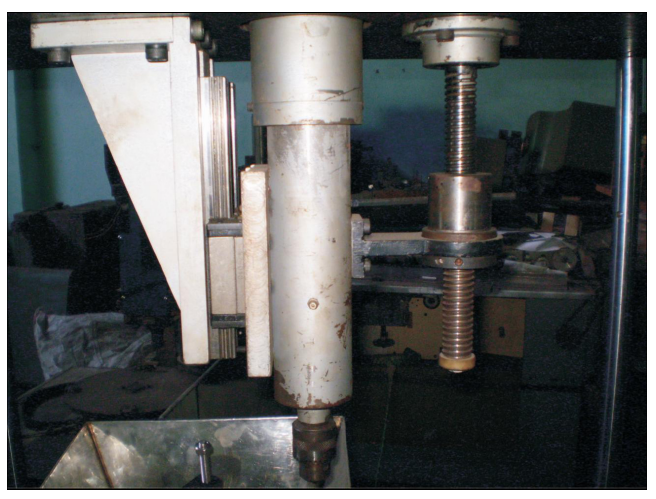

Figure 5 Z-motion mechanism

An additional rotational motion is perform by a DC motor with the belt transmission. This motion is used when necessary. The maximun rotational velocity is of $150 \mathrm{rpm}$.

\subsection{Electrical design and control circuit}

The $2 \mathrm{KW}$ pulse generator is designed and fabricated based on the resistor- capacitor type. By changing and combining the values of resistors and capacitors, we can supply different frequencies. The relationship between the obtained surface quality and the machining frequency is expressed as in the Figure 6. The higher the frequency is, the better the surface quality is.

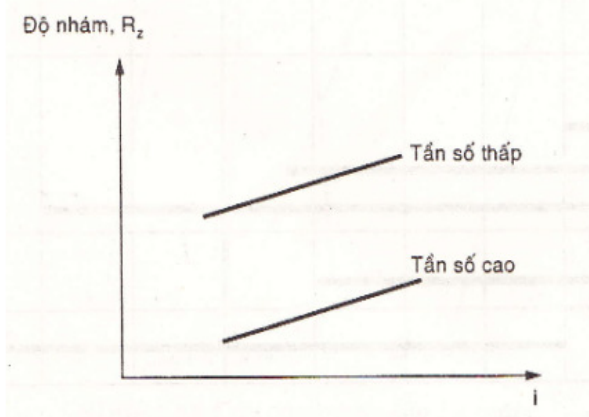

Figure 6 Influence of the machining frequency on the surface roughness [1]

The amplitude of the pulse is also an important parameter.

According to [1], the surface roughness depends on the energy of a pulse and has a profile as illustrated in figure 7

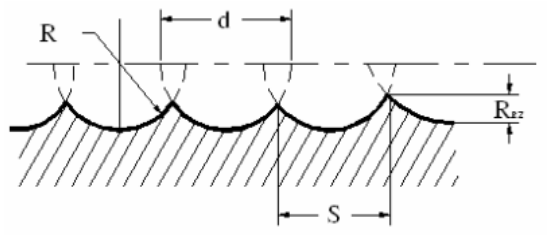

Figure 7. The surface roughness of workpiece obtained by EDM process [1]

A simple solution is chosen for the automatic vertical feeding motion. The tool electrode is driven with the aid of a DC print motor and the OP-AMP circuit illustrated in figure 8

The input signal is the potential between the two electrodes that varies with the spark 
gap while machining. This leads to the speed and the rotational direction of the driving motor.

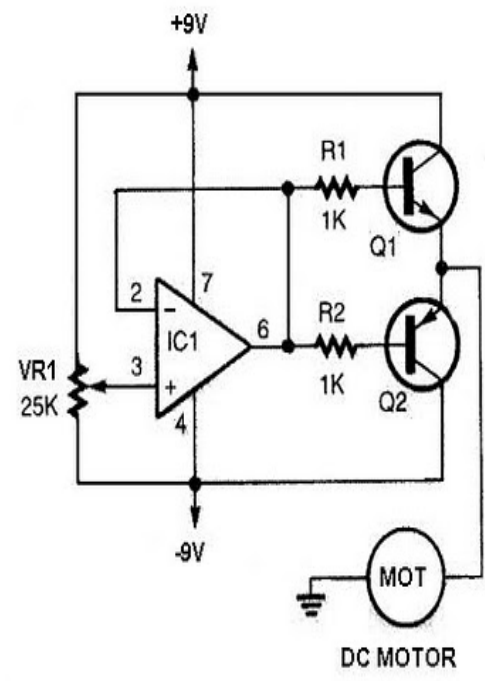

Figure 8. DC motor driving circuit

\subsection{Obtained workpieces}

Some typical workpieces machined with this EDM machine are presented in figure 9 and figure 10

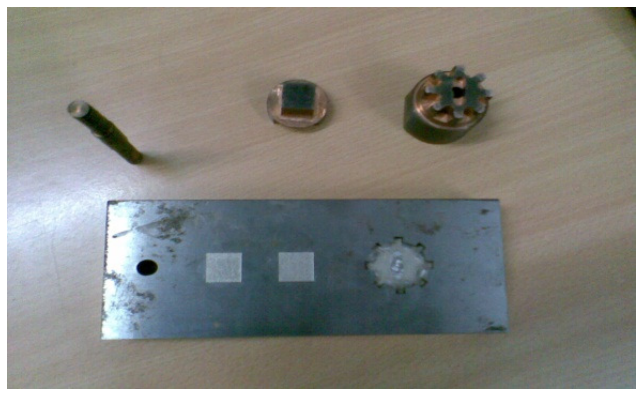

Figure 9. Copper tool electrodes and machined products

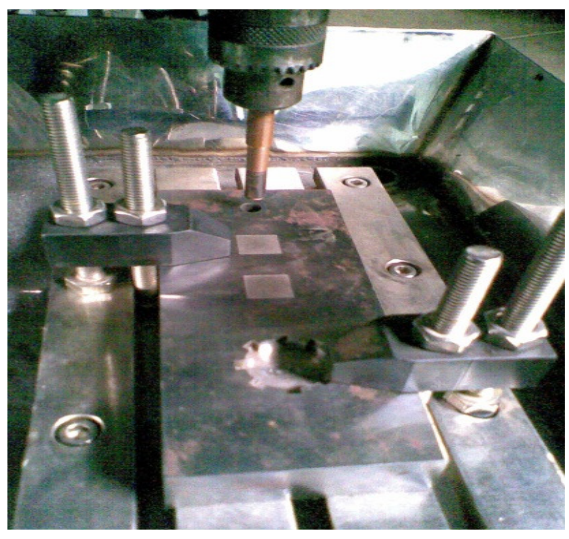

Figure 10. Fixture and the workpieces

\section{CONCLUSIONS}

A small R-C type EDM machine has been successfully designed and fabricated. Some initial results are obtained to establish the relationship between the surface roughness and the pulse parameters such as frequency, amplitude etc.

Other tests are being performed to investigate the productivity, the wearness ratio of the tool electrode with various materials. The machining precision is also our concern.

In the near future, a transistor type pulse generator will be studied and fabricated.

\section{Trang 72}




\section{THIẾT KẾ CHẾ TẠO MÁY TIA LỬA ĐIỆN LOẠI NHỎ}

\section{Phan Đình Huấn}

Faculty of Mechanical Engineering, Hochiminh City University of Technology National Key Lab of Digital Control and System Engineering, VNU-HCM

TÓM TÄT: Nội dung chính bài báo tập trung vào việc thiết kế chế tạo một máy gia công tia lưa điện nhằm đáp ứng nhu cầu trong nuớc về lãnh vục gia công các chi tiết máy có hình dáng hình học phức tạp, hoặc độ cứng vật liệu chi tiết cao, hoặc có yêu cầu cao về độ chính xác, về độ nhã̃n bề mặt. Với các truờng hợp trên, ta không thể gia công bằng các phuơng pháp gia công co truyền thống. Dựa trên các kết quả nghiên cưu về ngyên lý gia công tia lửa điện, các giải pháp điều khiển tư động điện cực dụng cụ, các loại vật tụ hiện có ở thị trường Việt nam, một máy gia công tia lửa điện đã được chế tạo thành công.Máy này gồm có phần cơ, phần điện (bộ phát xung), phần điều khiển tư động điện cưc, hệ thống bơm, lọc, chiếu sáng v.v...Các quá trình gia công EDM ban đầu cũng đã được thục hiện để xác định vài thông số công nghệ quan trọng cũng nhu đánh giá chất lượng gia công đạt được của máynày

Keywords: electrical discharge machining machine, EDM, automatic control mechanism

\section{REFERENCES}

[1]. Vũ Hoài Ân, Gia công tia lửa điện $C N C$, Nhà xuất bản Khoa học Kỹ thuật (2003).

[2]. Lưu Đức Bình, Tối ưu hóa quá trình gia công cắt dây tia lửa điện, Đại học Bách Khoa Đà nẵng.

[3]. Phan Hùng Dũng, Tối ưu hóa các thông số công nghệ trên máy cắt dây EDM khi gia công thép không gỉ, Đại học Kỹ Thuật Công Nghiệp Thái nguyên.

[4]. Đặng Anh Qui, Đặng Ngọc Quí, Thiết kế máy gia công tia lưa điện, đề tài luận văn tốt nghiệp kỹ sư ĐHBK TP.HCM (2011).
[5]. Hoàng Vĩnh Sinh, Nghiên cúu thiêt kế và chế tạo bộ điều khiển cho máy xung tia lủa điện trong điều kiện Việt Nam, Đại học Bách Khoa Hà nội.

[6]. Nguyễn Thanh Sơn, Thiết kế chế tạo mô phỏng máy EDM loại nhỏ, Luận văn tốt nghiệp Thạc sĩ, Đai học Bách Khoa TP HCM (2006).

[7]. Phạm Ngọc Tuấn, Nguyễn Văn Tường, Các phuoong pháp gia công đặc biệt, Nhà xuất bản Đại học Quốc gia TP.HCM (2007).

[8]. http://en.wikipedia.org/wiki/Electrical_d ischarge_machining 
[9]. http://www.docstoc.com/docs/50037010 Electrical-Discharge-Machine---Patent5808261

[10]. http://www.wikipatents.com/US-Patent5808261/electrical-discharge-machine

[11]. http://www.wikipatents.com/US-Patent5357073/electrical-discharge-machine

[12]. http://www.wikipatents.com/US-Patent6967303/electrical-discharge-machine
[13]. http://www.wikipatents.com/US-Patent5049715/electric-discharge-machine

[14]. http://www.wikipatents.com/US-Patent7202438/electrical-dischargemachining-apparatus

[15]. http://patents.com/us-7795558.html

[16]. http://elektroarea.blogspot.com/2011/04/ dc-motor-controller-circuit-using-

741.html 